Peter P. Neidhart MD, Paul Champion MD, John Vogel MD, Elemer K. Zsigmond MD,* Edömer Tassonyi MD

\title{
A comparison of pipecuronium with pancuronium on haemodynamic variables and plasma catecholamines in coronary artery bypass patients
}

\begin{abstract}
Pipecuronium bromide, a new neuromuscular relaxant with steroidal structure, is devoid of effects on the autonomic nervous system and may be useful in patients where haemodynamic stability is mandatory. However, tracheal intubation may alter this haemodynamic profile. Therefore, we carried out a prospective double-blind study in 30 patients undergoing coronary artery bypass surgery with the purpose (I) of determining if intubation influenced the haemodynamic stability in patients paralyzed with pipecuronium and (2) of comparing plasma catecholamine concentrations after pipecuronium with those afier pancuronium. Thirly patients were randomized into two groups receiving either pipecuronium $100 \mu \mathrm{g} \cdot \mathrm{kg}^{-1}$ or pancuronium $150 \mu \mathrm{g} \cdot \mathrm{kg}^{-1}$ afier induction of anaesthesia with midazolam and fentanyl. Haemodynamic variables and plasma catecholamines were measured before and after induction, after the muscle relaxant three times and twice after intubation. After anaesthesia induction decreases in heart rate (HR), mean arterial pressure (MAP) and cardiac index $(C I)$ were observed in both groups. These haemodynamic variables were unchanged
\end{abstract}

\section{Key words}

ANAESTHESIA: cardiac;

HEART: stimulation, ischaemia;

NEUROMUSCULAR RELAXANTS: pancuronium,

pipecuronium;

SYMPATHETIC NERVOUS SYSTEM: anaesthesia.

From the Department of Anaesthesiology, University Hospital of Geneva, Switzerland and Department of Anesthesiology, University of Illinois, Chicago*, USA.

Address correspondence to: Dr. P.P. Neidhart, University Hospital of Geneva, 24, rue Micheli-du-Crest, CH-1211

Geneva-14, Switzerland.

Accepted for publication 21 January, 1994. after pipecuronium whereas after pancuronium $H R$ increased from $53 \pm 11 \mathrm{~b} \cdot \mathrm{min}^{-1}$ to $64 \pm 9 \mathrm{~b} \cdot \mathrm{min}^{-1}$ after induction $(P<0.05)$ and $C I$ from $2.5 \pm 0.5 \mathrm{~L} \cdot \mathrm{min}^{-1}$ to $3.0 \pm 0.8$ $L \cdot \min ^{-1}(P<0.05)$. Furthermore ECG signs of myocardial ischaemia appeared in four patients after pancuronium and the decay of plasma norepinephrine concentration was slower than with pipecuronium. We conclude that pipecuronium given after induction of anaesthesia is free of sympathomimetic or vagolytic activity and does not influence haemodynamic variables for up to ten minutes after tracheal intubation.

Le bromure de pipecuronium est un nouveau myorelaxant avec une structure stéroïdale similaire au bromure du pancuronium avec lequel il partage les propriétés pharmacocinétiques sans pour autant exercer un effet sur le système nerveux autonome. Cependant lintubation endotrachéale effectuée après l'administration de ce myorelaxant pourrait changer son profil hémodynamique. C'est pourquoi nous avons effectué chez 30 patients devant subir une chirurgie coronarienne une étude prospective en double aveugle dans le but 1) dinvestiguer si lintubation endotrachéale change le profil hémodynamique chez le patient paralysé avec du pipecuronium et 2) de comparer les variations des taux plasmatiques des catécholamines après pipecuronium avec celles après pancuronium. Les patients sont randomisés en deux groupes selon le myorelaxant qui leur sera administré après l'induction anesthésique (midazolam-fentanyl) soit du pipecuronium $100 \mu \mathrm{g} \cdot \mathrm{kg}^{-1}$ soit du pancuronium $150 \mu \mathrm{g} \cdot \mathrm{kg}^{-1}$. Les variables hémodynamiques et les taux plasmatiques d'adrénaline et de noradrénaline sont mesurés une fois avant et une fois après linduction, trois fois avant et deux fois après l'intubation. Linduction anesthésique provoque une diminution significative de la fréquence cardiaque (FC), de la pression artérielle moyenne et de lindex cardiaque (IC). Ces variables hémodynamiques restent inchangées après le pipecuronium 
tandis que après le pancuronium une accélération de la FC de $53 \pm 11 \mathrm{~b} \cdot \mathrm{min}^{-1}$ à $64 \pm 9 \mathrm{~b} \cdot \mathrm{min}^{-1}(P<0.05)$ concomitante avec une augmentation de l'TC de $2.5 \pm 0.5 \mathrm{~L} \cdot \mathrm{min}^{-1}$ à $3.0 \pm 0.8 \mathrm{~L} \cdot \mathrm{min}^{-1}(P<0.05)$ sont observées. De plus, après l'administration de pancuronium on observe chez quatre patients des signes électrocardiographiques dischémie myocardique et le taux de norépinéphrine plasmatique diminue plus lentement qu'après le pipecuronium. En conclusion, nos résultats démontrent que le pipecuronium lorsquil est administré après linduction anesthésique est exempt d'effets sympathomimétique ou vagolytique et ne modifie pas les variables hémodynamiques jusqu'à $10 \mathrm{~min}$ après l'induction.

The use of pancuronium for muscle relaxation during narcotic-based anaesthesia is popular because its vagolytic ${ }^{\prime}$ and sympathomimetic ${ }^{2,3}$ properties tend to antagonize the untoward circulatory effects of opioids. However, in patients with coronary artery disease, a $25 \%$ incidence of myocardial ischaemia appeared on the electrocardiogram (ECG) during fentanyl-pancuronium induction of anaesthesia, which was higher than after other neuromuscular relaxants. ${ }^{4}$ Furthermore, these ECG changes were associated with an increase in heart rate of 28 to $57 \%$ above control, suggesting that pancuronium increased noradrenaline concentration at sympathetic nerve endings.

Pipecuronium bromide is structurally related to pancuronium $^{5}$ and shares its neuromuscular effects and pharmacokinetic properties, ${ }^{6-8}$ however, it is devoid of effects on the autonomic nervous system. ${ }^{9,10}$ We confirmed these observations in a previous study comparing the cardiovascular effects of three different doses of pipecuronium $\left(1,2\right.$ and $\left.3 \times E_{95}\right)$ with those of pancuronium $(2 \times$ $\left.E D_{95}\right)$ in the anaesthetized non-stimulated and nonintubated patient."

However, the influence of pipecuronium on haemodynamic variables and on plasma catecholamine concentrations before and after tracheal intubation has not been reported.

We therefore designed a double-blind, randomized study in patients undergoing coronary artery surgery with the aims of: (1) determining the cardiovascular effects and the catecholamine responses of pipecuronium administered during induction of anaesthesia and after tracheal intubation and (2) of comparing these effects with those after pancuronium.

\section{Methods}

After approval of the protocol by the institutional review board for human studies, informed consent was obtained from 30 patients (ASA physical status III) scheduled for elective coronary artery bypass surgery (CABG). Exclu- sion criteria were: emergency operation, unstable angina, left ventricular failure (clinical or proved at preoperative catheterisation), associated valvular heart disease, arterial hypertension, diabetes mellitus and liver or kidney disease. Patients whose preoperative ECG would have interfered with the interpretation of acute ST-segment changes during induction of anaesthesia and tracheal intubation, e.g., bundle branch block or left ventricular hypertrophy were also excluded. Preoperative betaadrenergic and/or calcium channel blocker therapy was continued up to the morning of surgery.

Patients were randomly assigned to one of two treatment groups: (1) Group PIP $(n=15)$ received pipecuronium at a dose of $100 \mu \mathrm{g} \cdot \mathrm{kg}^{-1}\left(=2 \times \mathrm{ED}_{95}\right)$ and (2) Group PAN $(n=15)$ received pancuronium at a dose of $150 \mu \mathrm{g} \cdot \mathrm{kg}^{-1}\left(=2 \times \mathrm{ED}_{95}\right)$. Equipotent concentrations of the two muscle relaxants were prepared and delivered to the operating room in coded syringes.

Patients were premedicated with diazepam 0.15 $\mathrm{mg} \cdot \mathrm{kg}^{-1}$ po and morphine $0.10 \mathrm{mg} \cdot \mathrm{kg}^{-1}$ im one hour before arrival in the anaesthesia induction room. In each patient a 20-gauge cannula was inserted into a radial artery and a triple lumen flow-directed pulmonary artery catheter in the pulmonary artery under local anaesthesia. Leads II and $V_{5}$ of the ECG were monitored continuously.

Anaesthesia was induced with midazolam 0.10 $\mathrm{mg} \cdot \mathrm{kg}^{-1} \dot{i}$ followed by fentanyl $0.015 \mathrm{mg} \cdot \mathrm{kg}^{-1} \dot{N}$ given over two minutes. Three minutes later the muscle relaxant was administered, and ten minutes after its administration the tracheas were intubated, always by the same experienced anaesthetist. During induction, ventilation was manually assisted using $100 \%$ oxygen and after administration of the relaxant, was controlled by face mask to maintain normocarbia, as assessed in line by capnography (Datex Capnomac). Heart rate (HR), systolic, diastolic and mean radial artery blood pressure (SAP, DAP, MAP), central venous pressure (CVP) and systolic, diastolic and mean pulmonary artery pressure (SPAP, DPAP, MPAP) were monitored continuously. Pulmonary capillary wedge pressure (PCWP) was recorded and thermodilution cardiac output $(\mathrm{CO})$ obtained in triplicate at each measurement time. Prior to each $\mathrm{CO}$ measurement, a calibrated ECG tracing of DII, $V_{1}$ and $\mathrm{V}_{5}$ was obtained (Hewlett-Packard Page Writer II). All recordings were examined for changes of the ST-T segment by a cardiologist not involved in the study. Changes were defined as significant if: (1) there was a downsloping or horizontal depression of $>1 \mathrm{~mm}$, or an upsloping of the ST segment $>2 \mathrm{~mm}$ measured $0.06 \mathrm{sec}$ from the $\mathrm{J}$ point or (2) the T-axis changed by $>30^{\circ}$.

Cardiac index (CI), stroke volume index (SVI), systemic and pulmonary vascular resistance indices (SVRI, 
PRVI) and the rate pressure product (RPP $=H R \times$ systolic arterial pressure) were calculated by standard formulae.

At each measurement time 5-7 $\mathrm{ml}$ arterial blood were withdrawn from the radial artery cannula and put into precooled heparinized tubes. The tubes were cold centrifuged and the decanted plasma was stored in a freezer at $-70^{\circ} \mathrm{C}$. Analysis of plasma concentrations of epinephrine (E) and norepinephrine (NE) was performed by highpressure liquid chromatography (HPLC), ${ }^{12,13}$ allowing detection of as few as $15 \mathrm{pg} \cdot \mathrm{ml}^{-1} \mathrm{NE}$ and $20 \mathrm{pg} \cdot \mathrm{ml}^{-1}$ E per sample injected in the column with a coefficient of variation of $9 \%$ for $\mathrm{E}$ and $10.3 \%$ for NE between different samples and $7 \%$ for $\mathrm{E}$ and $\mathrm{NE}$ within the same sample.

Haemodynamic measurements, ECG recordings and arterial blood sampling were performed at the following times: $t_{-10}$ : control before induction; $t_{0}$ : one minute after completion of induction; $t_{2}, t_{5}, t_{10}$ : two, five and ten minutes after neuromuscular relaxant; $t_{12}, t_{18}$ : two and eight minutes after tracheal intubation. The study ended with the last sampling of data seven to eight minutes after intubation.

All data are reported as mean $\pm \mathrm{SD}$. Differences between the various measurement times within one group were analyzed by ANOVA one-way analysis for repeated measures, followed by a Bonferroni test when the F-ratio resulted in a $P<0.05$. Differences between the two groups at the same measurement time were analyzed by Student's $t$ test for unpaired data. Chi-square analysis with Yates correction was used for proportions. A $P<0.05$ was considered significant.

\section{Results}

As illustrated in Table I and Figure 1, demographic data and preinduction $\left(t_{-10}\right)$ haemodynamic variables $H R$, MAP and CI were similar in both groups. Induction of anaesthesia with midazolam and fentanyl induced similar decreases of HR by $20 \%$, of MAP by $30 \%$ and of CI by $20 \%$ in both groups $(P<0.05$ compared with control at $t_{-10}$ ).

After pipecuronium HR, MAP and $\mathrm{CI}$ remained at postinduction values, whereas after pancuronium $H R$ and CI returned to preinduction values $(P<0.05$ compared with values at $T_{0}$ ).

The comparison between the two groups revealed that HR and MAP were higher in group PAN than in group PIP at $t_{2}$ and at all other measurement times following the administration of the muscle relaxants although the effect of pancuronium on MAP was very small. The difference in CI reached significance only at $t_{10}$, the last measurement before tracheal intubation. Changes in other haemodynamic variables were not significant and no dif-
TABLE I Preoperative demographic data (mean $\pm \mathrm{SD}$ or number (n) of patients)

\begin{tabular}{lll}
\hline & $\begin{array}{l}P I P \\
(n=15)\end{array}$ & $\begin{array}{l}P A N \\
(n=15)\end{array}$ \\
\hline Age $(y r)$ & $64 \pm 7$ & $60 \pm 10$ \\
Sex $($ male/female) $(n)$ & $13 / 2$ & $12 / 3$ \\
LVEF*(\%) & $50 \pm 1$ & $61 \pm 8$ \\
Preoperative antianginal treatment $\dagger(n)$ & 11 & 12 \\
Beta-blocker $(n)$ & 3 & 2 \\
Ca-channel antagonist $(n)$ & 4 & 5 \\
Combined treatment $(n)$ & 4 & 5 \\
\hline
\end{tabular}

*LVEF = left ventricular ejection fraction at preoperative catheterisation.

$\dagger$ Number of patients receiving beta-blocker, Ca-channel antagonists or both up to the morning of surgery.

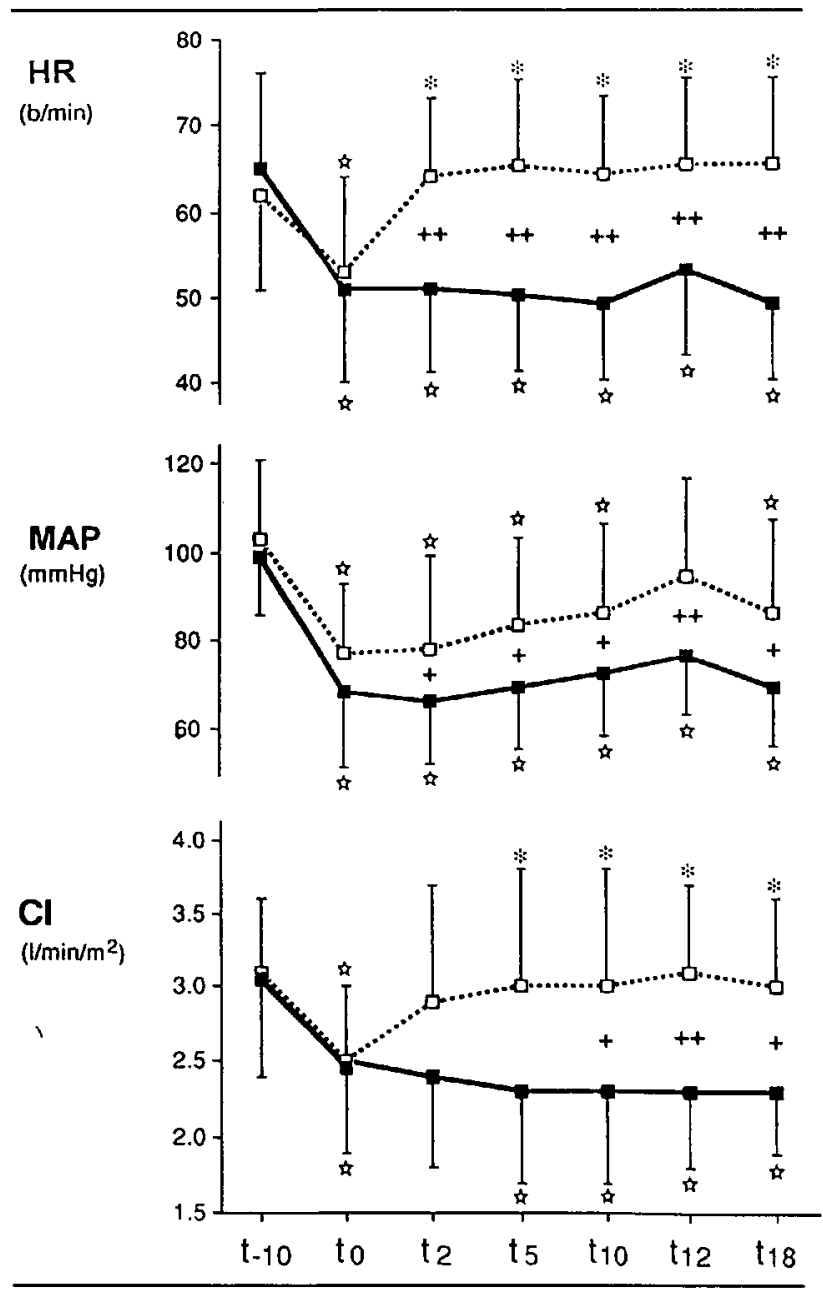

FIGURE 1 Comparison of heart rate (HR), mean arterial pressure (MAP) and cardiac index (CI) between Group PAN ( $\square$... $\square$ ) and group PIP ( $-\square$; (for abbreviations of the measurement times $\mathrm{cf}$. text).

$4 P<0.05$ compared with preinduction value.

$* P<0.05$ compared with postinduction value.

$+P<0.05 ;++P<0.01$; comparison between groups. 
TABLE II Synopsis of haemodynamic data

\begin{tabular}{|c|c|c|c|c|c|c|c|c|}
\hline $\begin{array}{l}\text { Haemodynamic } \\
\text { variables } \\
\text { (mean } \pm S D)\end{array}$ & $\begin{array}{l}\text { Neuro- } \\
\text { muscular } \\
\text { relaxant }\end{array}$ & $\begin{array}{l}\text { Pre- } \\
\text { induction } \\
\left(t_{-10}\right)\end{array}$ & $\begin{array}{l}1 \text { min after } \\
\text { induction } \\
\left(t_{0}\right)\end{array}$ & $\begin{array}{l}2 \text { min after } \\
\text { induction } \\
\left(t_{2}\right)\end{array}$ & $\begin{array}{l}5 \text { min afier } \\
\text { induction } \\
\left(t_{1}\right)\end{array}$ & $\begin{array}{l}10 \text { min after } \\
\text { induction } \\
\left(t_{10}\right)\end{array}$ & $\begin{array}{l}2 \text { min afier } \\
\text { intubation } \\
\left(t_{12}\right)\end{array}$ & $\begin{array}{l}8 \text { min after } \\
\text { intubation } \\
\left(t_{18}\right)\end{array}$ \\
\hline \multirow[t]{2}{*}{$H R\left(b \cdot \min ^{-1}\right)$} & PAN & $62 \pm 11$ & $53 \pm 11$ 사 & $\begin{array}{l}64 \pm 9 * \\
++\end{array}$ & $\begin{array}{l}65 \pm 10^{*} \\
++\end{array}$ & $\begin{array}{l}64 \pm 9^{*} \\
++\end{array}$ & $\begin{array}{l}65 \pm 10^{*} \\
++\end{array}$ & $\begin{array}{l}65 \pm 10^{*} \\
++\end{array}$ \\
\hline & PIP & $65 \pm 11$ & $51 \pm 11$ & $51 \pm 10$ & $50 \pm 9$ & $49 \pm 9 \not$ & $53 \pm 10$ & $49 \pm 9$ \\
\hline \multirow[t]{2}{*}{ MAP (mmHg) } & PAN & $103 \pm 18$ & $77 \pm 16$ & $\begin{array}{l}78 \pm 21 \\
+\end{array}$ & $\begin{array}{l}83 \pm 204 \\
+\end{array}$ & $\begin{array}{l}86 \pm 20 \\
+\end{array}$ & $\begin{array}{l}94 \pm 22 \\
+\end{array}$ & $\begin{array}{l}86 \pm 21 \\
+\end{array}$ \\
\hline & PIP & $99 \pm 13$ & $68 \pm 17$ & $66 \pm 14$ & $69 \pm 14$ & $72 \pm 14$ & $76 \pm 13$ & $69 \pm 13$ \\
\hline \multirow[t]{2}{*}{$\mathrm{CI}\left(\mathrm{L} \cdot \mathrm{min}^{-1} \cdot \mathrm{m}^{-2}\right)$} & PAN & $3.1 \pm 0.5$ & $2.5 \pm 0.5$ & $2.9 \pm 0.8$ & $3.0 \pm 0.8^{*}$ & $\begin{array}{l}3.0 \pm 0.8^{*} \\
+\end{array}$ & $\begin{array}{l}3.1 \pm 0.6^{*} \\
++\end{array}$ & $\begin{array}{l}3.0 \pm 0.6^{*} \\
+\end{array}$ \\
\hline & PIP & $3.1 \pm 0.7$ & $2.5 \pm 0.64$ & $2.4 \pm 0.6$ & $2.3 \pm 0.6$ & $2.3 \pm 0.6$ & $2.3 \pm 0.5$ & $2.3 \pm 0.4$ 다 \\
\hline \multirow{2}{*}{$\operatorname{SVI}\left(\mathrm{ml} \cdot \mathrm{m}^{-2}\right)$} & PAN & $51 \pm 7$ & $49 \pm 10$ & $45 \pm 11$ & $46 \pm 12$ & $46 \pm 10$ & $48 \pm 8$ & $46 \pm 8$ \\
\hline & PIP & $48 \pm 11$ & $50 \pm 12$ & $48 \pm 12$ & $46 \pm 10$ & $47 \pm 16$ & $45 \pm 10$ & $47 \pm 9$ \\
\hline \multirow{2}{*}{ CVP (mmHg) } & PAN & $8 \pm 3$ & $12 \pm 5$ & $9 \pm 4$ & $9 \pm 3$ & $9 \pm 4$ & $8 \pm 3$ & $8 \pm 3$ \\
\hline & PIP & $9 \pm 5$ & $10 \pm 4$ & $10 \pm 4$ & $10 \pm 4$ & $10 \pm 4$ & $10 \pm 4$ & $10 \pm 4$ \\
\hline \multirow{2}{*}{ MPAP (mmHg) } & PAN & $22 \pm 7$ & $20 \pm 3$ & $20 \pm 5$ & $20 \pm 4$ & $20 \pm 5$ & $20 \pm 6$ & $20 \pm 8$ \\
\hline & PIP & $24 \pm 9$ & $19 \pm 6$ & $19 \pm 5$ & $19 \pm 5$ & $19 \pm 5$ & $20 \pm 6$ & $18 \pm 5$ \\
\hline \multirow{2}{*}{ PCWP (mmHg) } & PAN & $14 \pm 6$ & $15 \pm 4$ & $12 \pm 4$ & $13 \pm 4$ & $13 \pm 4$ & $12 \pm 4$ & $11 \pm 3$ \\
\hline & PIP & $14 \pm 6$ & $14 \pm 5$ & $13 \pm 5$ & $13 \pm 4$ & $14 \pm 5$ & $13 \pm 4$ & $13 \pm 4$ \\
\hline
\end{tabular}

น $P<0.05$ compared with preinduction value.

$* P<0.05$ compared with postinduction value.

$+P<0.05$; $++P<0.01$; comparison between groups.

$\mathrm{HR}=$ heart rate, $\mathrm{MAP}=$ mean arterial pressure, $\mathrm{CI}=$ cardiac index, $\mathrm{SVI}=$ stroke volume index, $\mathrm{CVP}=$ central venous pressure, $\mathrm{MPAP}=$

mean pulmonary artery pressure, $\mathrm{PCWP}=$ pulmonary capillary wedge pressure, $\mathrm{PAN}=$ pancuronium, $\mathrm{PIP}=$ pipecuronium.

ferences between the two study groups were observed (Table II).

No differences were found between the two groups in the baseline $\left(t_{-10}\right) E$ or NE concentrations. Compared with the value at $\mathrm{t}_{0}=100 \%$, plasma NE concentrations in group PIP decreased to $66 \pm 30 \%$ before intubation $(P<0.05)$ and to $62 \pm 28 \%$ thereafter $\left(\mathrm{t}_{12}\right.$ and $\left.\mathrm{t}_{18}\right)(P$ $<0.05$ ). The corresponding values in group PAN were $83 \pm 34 \%$ at $\mathrm{t}_{10}(P<0.05)$ and $85 \pm 27 \%$ at $\mathrm{t}_{12}$ and $\mathrm{t}_{18}(P<0.05)$ respectively. Plasma NE concentrations were different between groups at three measurement times $t_{10}, t_{12}$ and $t_{18}$; no changes in plasma $E$ levels were observed in either of the two groups (Figure 2).

Electrocardiographic abnormalities suggesting myocardial ischaemia after the administration of the neuromuscular relaxant were observed in 4/15 patients in Group PAN and none in Group PIP. However, for technical reasons, a complete set of ECG recordings could be obtained only in 12 patients in group PIP. The ECG- changes in three of the four patients with myocardial ischaemia were not correlated with changes in haemodynamic variables, because HR and MAP did not differ from the mean values of the remaining patients without ECG-changes in group PAN. Only in the fourth patient did the HR increase from $60 \mathrm{~b} \cdot \mathrm{min}^{-1}$ at $\mathrm{t}_{0}$ to 82 and $86 \mathrm{~b} \cdot \mathrm{min}^{-1}$ after pancuronium.

\section{Discussion}

The results of the present study demonstrate that pipecuronium and pancuronium administered in equipotent doses during induction of anaesthesia differ not only in their haemodynamic effects, but also in their catecholamine-responses: plasma NE concentrations during the induction of anaesthesia decreased more when using pipecuronium than pancuronium. Furthermore, our results confirm previous reports of a high incidence of ECG changes, suggesting myocardial ischaemia after pancuronium. ${ }^{4}$ 


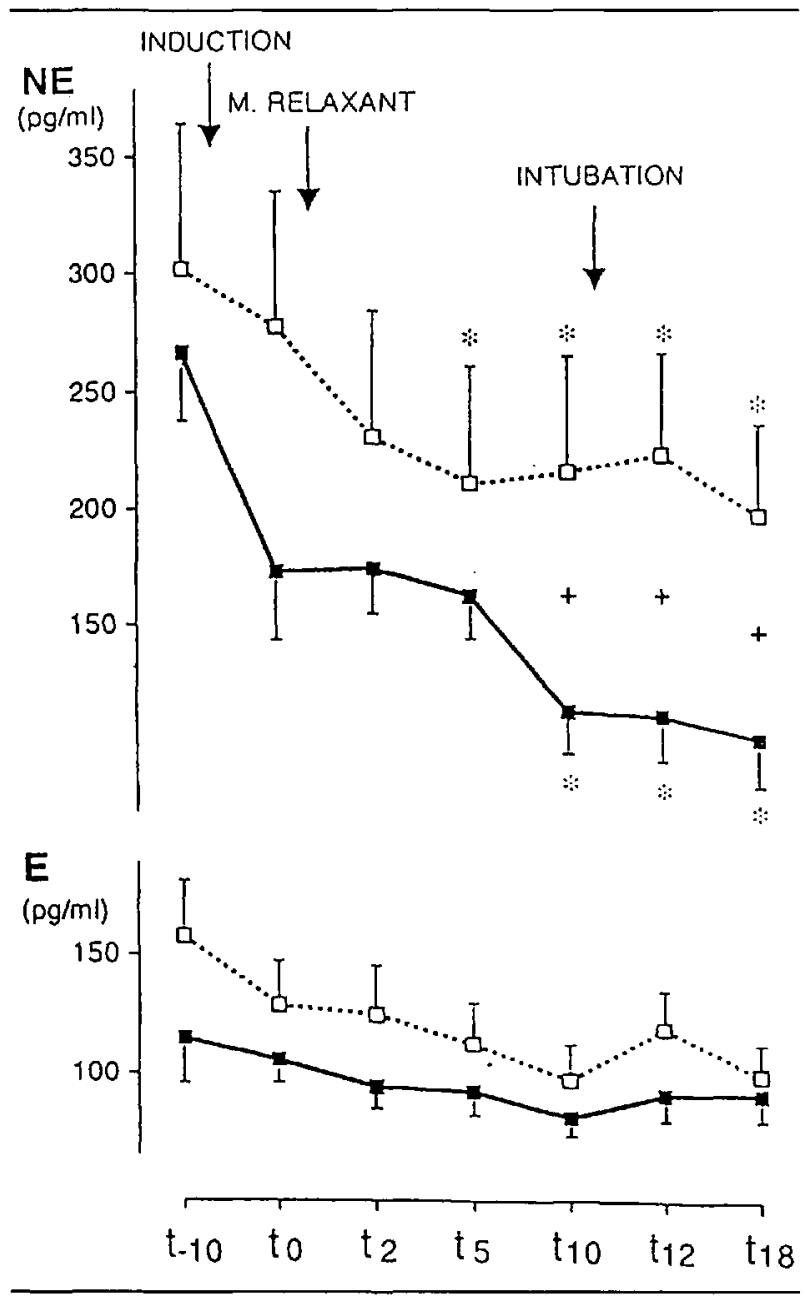

FIGURE 2 Comparison of plasma norepinephrine (NE) and epinephrine (E) concentrations in Group PAN $(\square \ldots \square)$ and Group PIP $(\square-\square) . * P<0.05$ compared with postinduction value. $+P<0.05$ comparison between groups.

In agreement with other studies, we demonstrated previously that pipecuronium, even when given in high doses $\left(3 \times \mathrm{ED}_{95}\right)$, is devoid of haemodynamic side effects. ${ }^{6,9,11}$ However, in that study ${ }^{11}$ only small amounts of midazolam $\left(0.1 \mathrm{mg} \cdot \mathrm{kg}^{-1}\right)$ and fentanyl $\left(5 \mu \mathrm{g} \cdot \mathrm{kg}^{-1}\right)$ were used and the study ended before tracheal intubation. In the present study, extending beyond intubation, we used a higher dose of fentanyl to suppress the sympathomimetic stimulation induced by orotracheal intubation. Contrary to pancuronium, pipecuronium did not induce any changes in the haemodynamic variables measured, either before or after intubation. This observation suggests that pipecuronium has no sympathomimetic or vagolytic effects to oppose opioid-induced bradycardia or "amplify" the sympathomimetic response to intubation. ${ }^{14,15}$

However, our investigation does confirm the results of previous studies, that the administration of a $2 \times \mathrm{ED}_{95}$ dose pancuronium after induction of anaesthesia induces a sustained increase in HR and CI regardless of the induction agent used. ${ }^{16-19}$ This side effect of pancuronium may be attributed to its vagolytic' ${ }^{\prime}$ or sympathomimetic properties, ${ }^{2,3,20}$ the latter probably being the reason that in our study MAP was higher after pancuronium than after pipecuronium.

Venous plasma NE provides a useful estimation of sympathetic outflow ${ }^{21}$ and, therefore, the higher plasma NE concentration we observed ten minutes after pancuronium compared with pipecuronium is supporting evidence that the cardiovascular effects of pancuronium may be caused by increased sympathetic nervous activity resulting either from pre- or post-ganglionic facilitation of NE-release, ${ }^{22,23}$ or by inhibition of NE-uptake. ${ }^{24}$ However, preoperative treatment with betablockers and calcium antagonists especially if given, as in our study, up to the morning of surgery, as well as the choice of anaesthetics used for premedication and induction of anaesthesia may have blunted the cardiovascular side effects of pancuronium ${ }^{25}$ without affecting its impact on sympathetic neural activity; and this increased sympathetic activity may have favoured the appearance of myocardial ischaemia. Smaller doses of pancuronium, ${ }^{26}$ or a specific sympatholytic medication may modify the influence of pancuronium on sympathic neural activity, reducing the incidence of myocardial ischaemia.

In this context, pipecuronium appears to be a good alternative, because the comparison of $2 \times \mathrm{ED}_{95}$ of pipecuronium with a similar dose of pancuronium clearly shows the advantage of pipecuronium over pancuronium with regard to haemodynamic stability and the incidence of myocardial ischaemia.

In conclusion, the cardiovascular and autonomic response to a given sequence of anaesthetic induction agents and tracheal intubation can be modified by the neuromuscular relaxant used. This observation may be important in patients with a compromised cardiovascular system.

\section{References}

1 Saxena PR, Bonta IL. Mechanism of selective cardiac vagolytic action of pancuronium bromide. Specific blockade of cardiac muscarinic receptors. Eur J Pharmacol 1970; 11: 332-6.

2 Domenech JS, Garcia RC, Sasiain JMR, Loyola AQ Oroz JS. Pancuronium bromide: an indirect sympathomimetic agent. Br J Anaesth 1976; 48: 1143-8.

3 Salt PJ, Barnes PK, Conway CM. Inhibition of neuronal uptake of noradrenaline in the isolated perfused rat heart by pancuronium and its homologues, Org. 6368, Org. 7268 and NC 45. Br J Anaesth 1980; 52: 313-7.

4 Thomson IR, Putnins CL. Adverse effects of pancuro- 
nium during high-dose fentanyl anesthesia for coronary artery bypass grafting. Anesthesiology 1985; 62: 708-13.

5 Tuba Z. Synthesis of 2 beta, 16 beta-bis (4'-dimethyl-1'piperazino)- 3 alpha, 17 beta-diacetoxy-5 alpha-androstane dibromide and related compounds. Arzneimittelforschung 1980; 30: 342-5.

6 Wierda JMKH, Karliczek GF, Vandenbrom RHG, et al. Pharmacokinetics and cardiovascular dynamics of pipecuronium bromide during coronary artery surgery. Can J Anaesth 1990; 37: 183-91.

7 Caldwell JE, Castagnoli KP, Canfell PC, et al. Pipecuronium and pancuronium: comparison of pharmacokinetics and duration of action. Br J Anaesth 1988; 61: 693-7.

8 Boros M, Szenohradszky J, Marosi G, Toth I. Comparative clinical study of pipecuronium bromide and pancuronium bromide. Arzheimittelforschung 1980; 30: 389-93.

9 Foldes $F F$, Nagashima $H$, Nguyen $H D$, Duncalf $D$, Goldiner $P L$. Neuromuscular and cardiovascular effects of pipecuronium. Can J Anaesth 1990; 37: 549-55.

10 Kárpáti $E$, Biró $K$. Pharmacological study of a new competitive neuromuscular blocking steroid, pipecuronium bromide. Arzneimittelforschung 1980; 30: 436-54.

11 Tassonyi E, Neidhart P, Pittet JF, Morel DR, Gemperle M. Cardiovascular effects of pipecuronium and pancuronium in patients undergoing coronary artery bypass grafting. Anesthesiology 1988; 69: 793-6.

12 Davis GC, Kissinger PT, Shoup RE. Strategies for determination of serum or plasma norepinephrine by reversephase liquid chromatography. Anal Chem 1981; 53: 156-9.

13 Goldstein DS, Feuerstein G, Izzo JL, Kopin IJ, Keiser $H R$. Validity and reliability of liquid chromatography with electrochemical detection for measuring plasma levels of norepinephrine and epinephrine in man. Life Sci 1981; 28: 467-75.

14 Russel WJ, Morris RG, Frewin DB, Drew SE. Changes in plasma catecholamine concentrations during endotracheal intubation. Br J Anaesth 1981; 53: 837-9.

15 Derbyshire $D R$, Chmielewski A, Fell D, Vater M, Achola $K$, Smith $G$. Plasma catecholamine responses to tracheal intubation. Br J Anaesth 1983; 55: 855-9.

16 Sethna DH, Starr NJ, Estafanous FG. Cardiovascular effects of non-depolarizing neuromuscular blockers in patients with coronary artery disease. Can Anaesth Soc J 1986; 33: 280-6.

17 Lavery GG, Mirakhur RK, Clarke RSJ, Gibson FM, Lowry KG. Does the choice of the neuromuscular blocking agent affect the cardiovascular response to intubation? Acta Anaesthesiol Scand 1987; 31: 239-43.

18 Gravlee GP, Ramsey FM, Roy RC, Angert KC, Rogers $A T$, Pauca $A L$. Rapid administration of a narcotic and neuromuscular blocker: a hemodynamic comparison of fen- tanyl, sufentanil, pancuronium, and vecuronium. Anesth Analg 1988; 67: 39-47.

19 Salmenperä M, Peltola K, Takkunen O, Heinonen J. Cardiovascular effects of pancuronium and vecuronium during high-dose fentanyl anesthesia. Anesth Analg 1983; 62: 1059-64.

20 Nana A, Cardan E, Domokos $M$. Blood catecholamine changes after pancuronium. Acta Anaesthesiol Scand 1973; 17: 83-7.

21 Goldstein DS, McCarty R, Polinsky RJ, Kopin IJ. Relationship between plasma norepinephrine and sympathetic neural activity. Hypertension 1983; 5: 552-9.

22 Gardier RW, Tsevdos E, Jackson DB. The effect of pancuronium and gallamine on muscarinic transmission in the superior cervical ganglion. J Pharmacol Exp Ther 1978; 204: 46-53.

23 Vercruysse P, Bossuyt P, Hanegreefs G, Verbeuren TJ, Vanhoute $P M$. Gallamine and pancuronium inhibit pre- and postjunctional muscarinic receptors in canine saphenous veins. J Pharmacol Exp Ther 1979; 209: 225-30.

24 Docherty JR, McGrath JC. Sympathomimetic effects of pancuronium bromide on the cardiovascular system of the pithed rat: a comparison with the effects of drugs blocking the neuronal uptake of noradrenaline. $\mathrm{Br} \mathrm{J}$ Pharmacol 1978; 64: 589-99.

25 Knight AA, Hollenberg $M$, London $M J$, et al. Perioperative myocardial ischemia: importance of the preoperative ischemic pattern. Anesthesiology 1988; 68: 681-8.

26 Kumar SM, Kothary SP, Zsigmond EK. The effect of pancuronium on plasma free-norepinephrine and epinephrine in adult cardiac surgical patients. Acta Anaesthesiol Scand 1978; 22: 423-9. 